\title{
Repair of a Cleft Palate in a Child with Hemophilia A
}

\author{
Kunio Ikemura', Akira ShIRAhata ${ }^{2}$ and Toshio NAKAMURA ${ }^{2}$ \\ 'Department of Dentistry and Oral Surgery, Hospital, University of Occupational and \\ Environmental Health, Japan. Kitakyushu 807, Japan \\ ${ }^{2}$ Department of Pediatrics, School of Medicine, University of Occupational and \\ Environmental Health, Japan. Kitakyushu 807, Japan
}

\begin{abstract}
The repair of a cleft palate in a child with severe hemophilia A was performed under replacement of factor VIII. The plasma level, over $50 \%$ of the normal value, was maintained during surgery. The estimated blood loss during surgery was $15 \mathrm{ml}$. In order to control postoperative bleeding, it is recommended that the factor VIII level be maintained above $30 \%$ for two weeks.
\end{abstract}

Key words: hemophilia A, cleft palate.

(Received 19 January 1983)

\section{Introduction}

Although many reports about the management of oral bleeding in hemophiliac patients have been published, they have focused on dental extractions. The association of a cleft palate with hemophilia A seems to be very uncommon. Since the report of Hussein et al. (1966), there has been no report in the literature.

This is a report of a case with cleft palate associated with severe hemophilia $\mathrm{A}$, and the general and local hemostatic treatments are described.

\section{Report of a Case}

A 30-month-old boy was referred to our university hospital for the repair of a cleft palate and the management of hemophilia. There was no bleeding disorders in his family. The patient was born on July 27, 1978 with a cleft lip and palate. At the age of one month, he was admitted for treatment of pneumonia. When a venipuncture was performed, unusual bleeding occurred. A diagnosis of hemophilia A was made at this hospital. When the child was 12 months old, his cleft lip was repaired under replacement of factor VIII at another university hospital. Thereafter, he received factor VIII replacement therapy 10 times because of gingival bleeding.

Preoperative examination: On admission, on April 17, 1981, his body weight was 13.5 $\mathrm{kg}$. The repair of an incomplete cleft lip on the left side was satisfactory. The cleft of 
the palate reached from the soft palate to the hard palate posterior to the incisive foramen (Fig. 1). There was no involvement of the alveolar ridge. The laboratory data of coagulation study are presented in Table 1. Other routine examinations revealed no abnormality. The whole blood coagulation time and activated partial thromboplastin time (APTT), which was performed using the modified Proctor's method, were significantly prolonged. His factor VIII activity assayed by Hardisty's one stage procedure (1962) was less than 1 per cent of normal subjects. The levels of factor VIII related antigen measured by Laurell's method (1966) and von Willebrand factor measured by Weiss's method (1973) were 134 per cent and 106 per cent respectively. Plasma factor VIII level was observed following a single infusion of the lyophilized factor VIII concentrate (Confact $8^{\circledR}$, Kaketsuken, Kumamoto, Japan) as shown in Fig. 2.

Operation: The palatoplasty was carried out on April 17, 1981, when the patient was 2 years and 7 months old. The factor VIII concentrate was infused one hour prior to surgery and followed by tranexamic acid (AMCA, Transamin ${ }^{B}$ ) (Fig. 3). Under general anesthesia (halothane), the V-Y pushback palatoplasty was performed (Fig. 1). Local hemostatic treatment was done as follows: local infiltration of 1: 200,000 epinephrine solution in 0.5 per cent lidocaine, meticulous hemostasis using the electric cautery, application of Thrombin Topical ${ }^{\mathbb{B}}$ and Gelfoam ${ }^{\mathrm{B}}$ to cover the raw surface and packing with gauze pads, which were laid under a dental splint. The palatal mucosa was closed with absorbable sutures (Dexon ${ }^{\mathrm{B}}$ ). The blood appeared to clot normally and the patient lost only an estimated $15 \mathrm{ml}$ of blood during surgical intervention. Postinfusion blood sam-

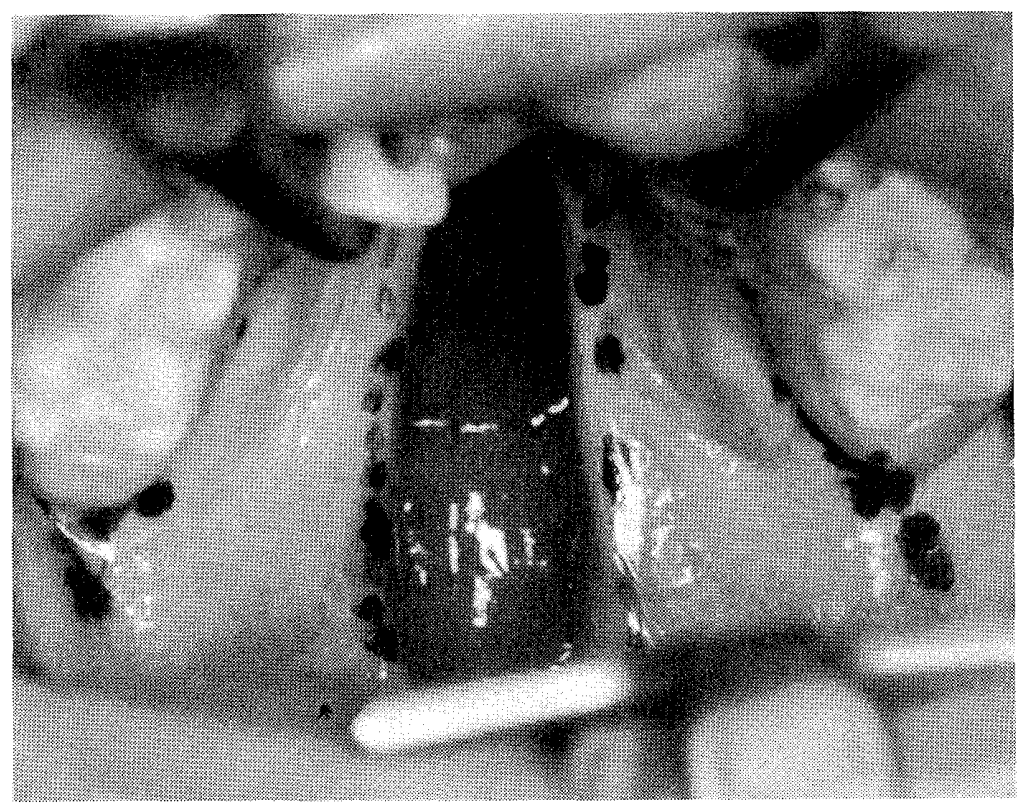

Fig. 1. The preoperative state of the palate and the incision line for the V-Y pushback palatoplasty. 
Table 1. Results of hematological examination

$\begin{array}{ll}\text { Platelet count } & 27.1 \times 10^{4} \text { per cu mm } \\ \text { Bleeding time (Duke) } & 5 \mathrm{~min} \\ \text { Coagulation time (Lee-White) } & 25 \mathrm{~min} \\ \text { Tourniquet test(Rumpel-Leede) } & \text { Negative } \\ \text { Prothrombin time (Quick) } & 12.2 \mathrm{sec}(\text { control } 12.0 \mathrm{sec}) \\ \text { Activated partial thromboplastin time } & 70.7 \mathrm{sec}(\text { control } 29.1 \mathrm{sec}) \\ \text { Fibrinogen level } & 171 \mathrm{mg} \mathrm{per} \mathrm{dl} \\ \text { Factor VIII activity } & \text { Less than } 1 \% \\ \text { Factor VIII related antigen } & 136 \% \\ \text { Von Willebrand factor activity } & 106 \% \\ \text { Factor VIII inhibitor } & \text { Not detected }\end{array}$

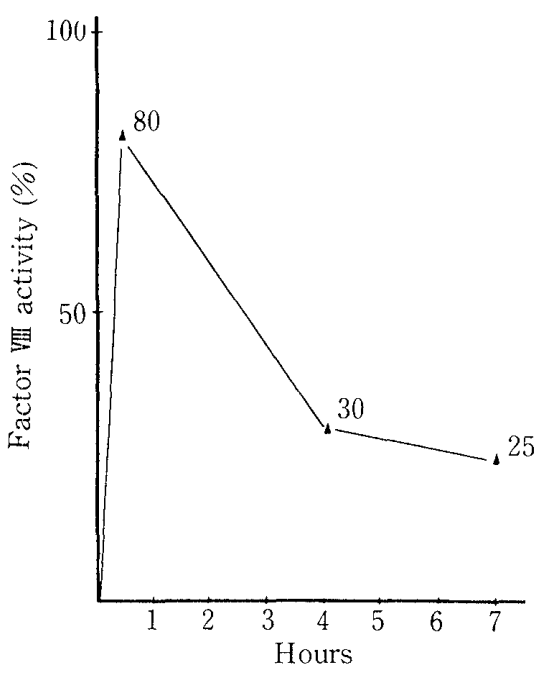

Fig. 2. Observation of the dose-response and the survival time following a single infusion of approximately 30 unit per kilogram of factor VIII.

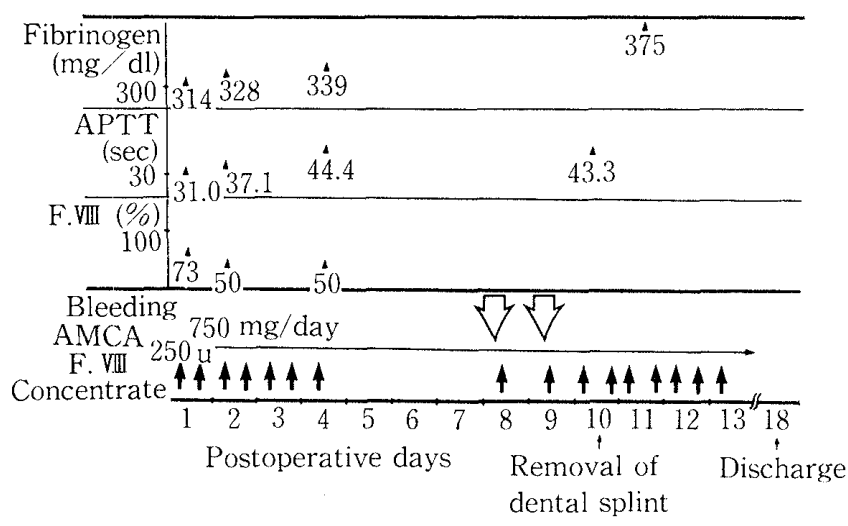

Fig. 4. The postoperative course.

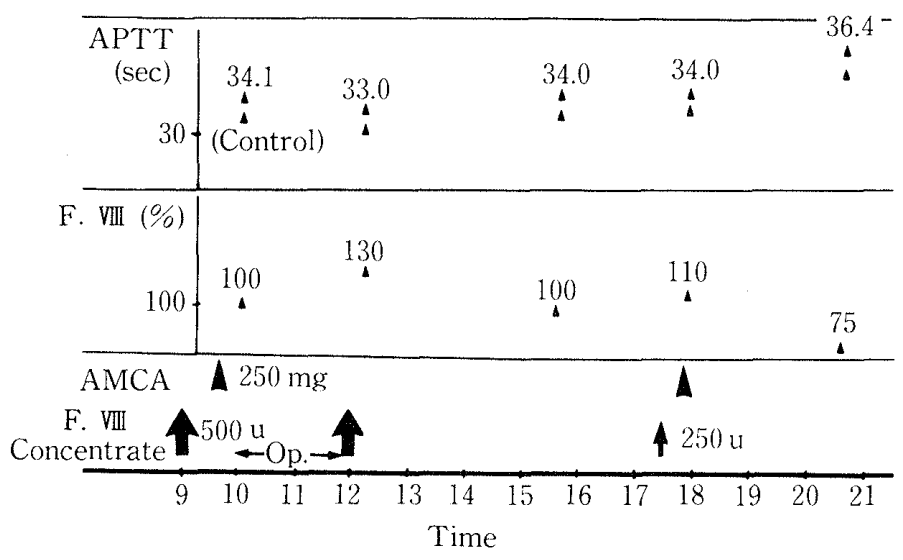

Fig. 3. The course of the operation day.

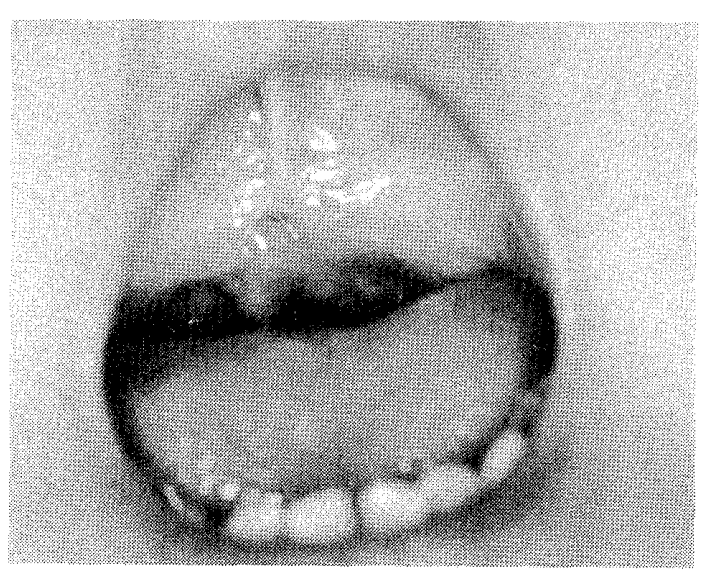

Fig. 5. The intraoral view 30 days after surgery. 
ples were taken and the plasma level of factor VIII and APTT were estimated (Fig. 3).

Postoperative course: The factor VIII concentrate and tranexamic acid were given as seen in Fig. 4. Administration of the antibiotics was continued for 14 days. On the eighth and ninth day oral bleeding occurred and hemostasis was obtained with replacement of factor VIII. Before the removal of the dental splint, the infusion of the factor VIII concentrate was started. On the tenth day the dental plate was removed without bleeding. Thereafter, no further bleeding occurred (Fig. 4). The patient was discharged 18 days after surgery. Hyperfibrinogenemia was not recognized. The wound healing was normal (Fig. 5). Speech therapy was continued for one year and the patient can now speak normally. An inhibitor against factor VIII as well as hepatitis has not occurred up to the present.

\section{Discussion}

The advent of the factor VIII concentrate significantly contributes to controlling hemorrhagic episodes in hemophiliacs. Britton et al. (1974) reported that one unit of factor VIII per kilogram infused yielded an approximate rise of 2 per cent and the mean initial 50 per cent disappearance time following infusions of the factor VIII concentrate was 5.2 hours. In our case, single infusion of 400 units (body weight $12.5 \mathrm{~kg}$ ) resulted in a rise of 80 per cent and the 50 per cent disappearance time was about 3 hours (Fig. 2). It means that the observed rise of factor VIII is higher than the expected rise and the disappearance time is shorter than average. A proper dosage of factor VIII concentrate depends on a variety of factors including, severity of the bleeding defect, the survival time of the infused factor, the degree of surgical intervention and the site of surgery. Hussein et al. (1966) reported that a blood sample taken at the beginning of the operation showed the AHG level to be 30 per cent of average normal and there was more general oozing towards the end of the operation. Donaldson \& Kisker (1974) describe that for major trauma or surgery a level of 50 per cent is at least required. For surgery in patients with hemophilia A, Krieger et al. (1977) recommend that a patient's plasma level should be brought to 100 per cent just prior to surgery and a level of more than 60 per cent be maintained for 4 days. We maintained the plasma level at more than 50 per cent during surgery. The factor VIII concentrate was infused as demonstrated in Fig. 3 and the estimated blood loss was only $15 \mathrm{ml}$.

We used tranexamic acid in order to minimize postoperative bleeding and diminish the volume of factor VIII concentrate, because there were reports that it was effective in controlling bleeding after extraction of teeth in hemophiliacs (Forbes et al., 1972; Tavenner, 1972). Tranexamic acid was given in a dosage of $250 \mathrm{mg}$ every eight hours. However, administration of tranexamic acid and the local hemostatic treatment, without replacement therapy, were not sufficient to control postoperative bleeding (Fig. 
4). Rudowski (1981) mentioned that for major surgery in hemophiliac patients a level over $30 \%$ of the normal value should be maintained until healing of the wound is complete. Considering the postoperative course of the case reported by Hussein et al. (1966) and our experience (Fig. 4), his opinion seems to be applicable to the palatoplasty in the hemophiliac child. Therefore, it is recommended that the factor VIII level be maintained above 30 per cent during the postoperative two weeks.

\section{Acknowledgement}

We wish to thank Professor K. Ohsato, Department of Surgery, University of Occupational and Environmental Health, Japan for criticism of the manuscript. We also thank Miss M. Shiiki for helping in the performance of the hematological examination.

\section{References}

Britton, M., Harrison, J. \& Abildgaard, C. F. (1974): Early treatment of hemophilic hemarthroses with minimal dose of new factor VIII concentrate. J. Pediatr., 85: 245-247.

Donaldson, V. H. \& Kisker, C. T. (1974): Blood coagulation in hemostasis. In: Hematology of Infancy and Childhood. (Nathan, D. G. \& Oski, F. A., ed.). W. B. Saunders, Philadelphia. P. 578.

Forbes, C. D., Barr, R. D., Reid, G. et al. (1972): Tranexamic acid in control of haemorrhage after dental extraction in haemophilia and Christmas disease. Brit. Med. J., 6: 311-313.

Hardisty, R. M. \& Macpherson, J. C. (1962): A one-stage factor VIII (antihaemophilic globulin) assay and its use on venous and capillary plasma. Thromb. Diath. Haemorrh, 7: 215-229.

Hussein, M. A. F., Matthews, J. M. \& Weber, A. B. (1966): The management of a complete cleft of the lip and palate in a baby with severe classical haemophilia. Brit. J. Plast. Surg., 19: 220-225.

Krieger, J. N., Hilgartner, M. W. \& Redo, S. F. (1977): Surgery in patients with congenital disorders of blood coagulation. Ann. Surg., 185: 290-294.

Laurell, C. B. (1966): Quantitative estimation of proteins by electrophoresis in agarose gel containing antibodies. Anal. Biochem., 15: 45-52.

Rudowski, W. J. (1981): Major surgery in haemophilia. Ann. R. Coll. Surg. Engl., 63: 111-117.

Tavenner, R. W. H. (1972): Use of tranexamic acid in control of haemorrhage after extraction of teeth in haemophilia and Christmas disease. Brit. Med. J., 6: 314-315.

Weiss, H. J., Hoyer, L. W., Rickles, F. R. et al. (1973): Quantitative assay of a plasma factor deficient in von Willebrand's disease that is necessary for platelet aggregation. J. Clin. Invest., 52: 2708-2716. 
血友病 $\mathrm{A}$ 患児の口蓋形成術

池村 邦男 ${ }^{1} \cdot$ 白幡聡 ${ }^{2}$ 中村外士雄 ${ }^{2}$

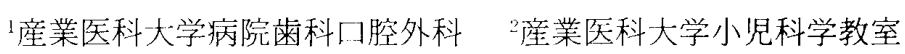

要 旨： 2 才 7 力の重症血友病 $\mathrm{A}$ 患者の曰蓋形成術を行ったので, 術中, 術後の出血管理につ いて著者らの経験を述べた。術中第四因子の補充（活性レベル 50\%以上）により出血量 を少量（約 $15 \mathrm{ml}$ ) に止得た。また, 術後出血の抑制のためには約 2 週間の補充療法（活 性レベル 30\%以上) が必要であると思われた。

J. UOEH (産業医大誌)，5(2): 277-282 (1983) 